\title{
The Genetic Factor in Acute Myocardial Infarction With Hypertension
}

\author{
Shuichi Aoki, MD; Shuji Mukae, MD; Seiji Itoh, MD; \\ Ryuji Sato, MT; Kazuaki Nishio, MD; \\ Toshiki Iwata, MD; Takashi Katagiri, MD
}

\begin{abstract}
This study assessed the contribution of polymorphisms of angiotensin II (AngII) receptors and bradykinin B2 (BKB2) receptor to hypertension and acute myocardial infarction (AMI) in a Japanese population: 150 subjects with essential hypertension, 150 subjects with AMI with/without hypertension, and 150 healthy, age- and sex-matched controls. Polymorphisms of the AngII type 1 receptor $(1166 \mathrm{~A} / \mathrm{C})$ and type 2 receptor $(3123 \mathrm{C} / \mathrm{A})$, and the BK-B2 receptor $(-58 \mathrm{~T} / \mathrm{C}$, exon 1$)$ were analyzed and significant differences of genotypes and allelic frequencies in the AngII type 2 receptor C/A and BK-B2 receptor $-58 \mathrm{~T} / \mathrm{C}$ were found between the essential hypertension and control subjects. Further, a significantly higher incidence of the $\mathrm{C}$ allele of the BK-B2 receptor was seen in AMI subjects with hypertension compared with those without hypertension. Genetic variations in the AngII and BK-B2 receptors could prove to be significant pathophysiological mechanisms affecting essential hypertension and AMI, and genetic differences appear to be a new risk factor for these conditions. (Jpn Circ J 2001; 65: 621-626)
\end{abstract}

Key Words: Acute myocardial infarction; Angiotensin II receptor; Bradykinin B2 receptor; Essential hypertension; Polymorphism

$\mathbf{M}$ ultiple environmental and genetic factors are involved in the pathogenesis of essential hypertension and coronary heart disease $!^{1-3}$ Because of its pivotal role in cardiovascular volume and pressure homeostasis, the renin-angiotensin system (RAS) has been a major focus of research into the causation of these diseases. From a genetic basis, recent advances in molecular biology have highlighted the importance of the RAS, and polymorphisms within this important system are candidates for elucidating the pathogenesis of essential hypertension and coronary heart disease. A microsatellite polymorphism near the angiotensinogen gene has been shown to be linked to essential hypertension in Utah and French Caucasian families, and 2 missense mutations in exon 2 (T174M and M235T) have been shown to be associated with higher plasma angiotensinogen levels and with essential hypertension. A variant located in the 3' untranslated region of the angiotensin II (AngII) type 1 receptor gene $(1166 \mathrm{~A} / \mathrm{C})$ is associated with essential hypertension in French Caucasians homozygous for the $\mathrm{C}$ allele. In addition, investigators have described 2 genetic susceptibility factors for myocardial infarction (MI) that act synergistically on components of the RAS; that is, the insertion/deletion (I/D) polymorphism of the angiotensin I converting enzyme (ACE) gene and the $1166 \mathrm{~A} / \mathrm{C}$ transversion of the angiotensin II type 1 receptor gene.,7

On the other hand, in recent years, the clinical use of ACE inhibitors has been increasing for the treatment of hypertension, congestive heart failure, and MI. The ability

(Received November 13, 2000; revised manuscript received March 19, 2001; accepted April 3, 2001)

Third Department of Internal Medicine, Showa University School of Medicine, Tokyo, Japan

Mailing address: Shuji Mukae, MD, Third Department of Internal Medicine, Showa University School of Medicine, 1-5-8 Hatanodai, Shinagawaku, Tokyo 142-8666, Japan of ACE inhibitors to decrease AngII production and increase the activity of the kininogen-kinin (bradykinin) system is considered to be critically important. Reduced formation of AngII and increased kinin levels contribute to the beneficial effects of ACE inhibitors, including the antihypertensive action and cardioprotection. For these reasons, the kallikrein-kinin system is also important in the pathogenesis of essential hypertension and coronary heart disease.

We have already reported that the bradykinin B2 (BKB2) receptor -58 thymine (T)/cytosine (C) promoter polymorphism was associated with essential hypertension in a Japanese population, and Braun et al support our data when they reported that the luciferase promoter assay of $-58 \mathrm{C}$ in the BK-B2 receptor was lower than that of $-58 \mathrm{~T}$ ?

Given the important roles of AngII and bradykinin as modulators of vasoactivity, both deleterious and beneficial effects of these polymorphisms are suspected at the different stages of atherosclerosis and during the acute or chronic events that lead to essential hypertension and coronary heart disease. We investigated this hypothesis in a case-control study in a Japanese population, comparing patients who survived essential hypertension and acute myocardial infarction (AMI) with appropriate control subjects, and how polymorphisms of the AngII type 1 and type 2 receptors in the RAS and the BK-B2 receptor in the kallikrein-kinin system contribute to essential hypertension and the development of hypertension (ie, acceleration of atherosclerosis and the occurrence of AMI).

\section{Methods}

We retrospectively studied the genetic susceptibility to essential hypertension and AMI by examining the polymorphisms of the AngII type 1 and type 2 receptors of the RAS, and the BK-B2 receptor of the kallikrein-kinin system in 450 participants randomly selected from inpa- 
Table 1 Clinical Characteristics of the Hypertensive, Control and Acute Myocardial Infarction Subjects

\begin{tabular}{|c|c|c|c|c|c|c|c|}
\hline & No. $($ male/female $)$ & Age (years) & $p$ value & $B P$ & $H C(\%)$ & $D M(\%)$ & $S M(\%)$ \\
\hline Hypertensive subjects & $150(105 / 45)$ & $53 \pm 10$ & NS & $148 \pm 8 / 94 \pm 6$ & 0 & 0 & 35 \\
\hline Control subjects & $150(103 / 47)$ & $52 \pm 8$ & & $120 \pm 10 / 82 \pm 6$ & 0 & 0 & 33 \\
\hline AMI subjects with hypertension & $69(47 / 22)$ & $64 \pm 7$ & $N S$ & & 31 & 33 & 59 \\
\hline AMI subjects without hypertension & $81(55 / 26)$ & $63 \pm 8$ & & & 30 & 33 & 60 \\
\hline
\end{tabular}

Age is expressed as mean \pm standard deviation, and comparison was performed by ANOVA. BP, blood pressure; HC, hypercholesterolemia; DM, diabetes mellitus; SM, smoking.

tients and outpatients at Showa University Hospital and allied hospitals in Tokyo, Japan. All study subjects were Japanese.

First, 150 non-treated essential hypertension outpatients were randomly selected. Hypertension was diagnosed according to the following criteria: (a) systolic blood pressure was $\geq 140 \mathrm{mmHg}$ or diastolic blood presssure was $\geq 90$ $\mathrm{mmHg}$ without anti-hypertensive treatment, and the patient had a history of hypertension for more than 1 year; (b) the patient did not have clinical or biological signs of secondary hypertension; and (c) the patient did not have coronary heart disease, hyperlipidemia, diabetes mellitus, etc requiring treatment. The average blood pressure in these hypertensive subjects was 148/94 (168-140/102-90), therefore the hypertensive subjects in this group had mild hypertension.

Second, 150 healthy normotensive subjects on routine visits to a medical examination center (Tokyo, Japan) were recruited as controls. They were age- and sex-matched to the hypertensive subjects and accepted into the study if the systolic blood presssure and diastolic blood presssure were $<140$ and $<90 \mathrm{mmHg}$, respectively, and there was not a familial history of hypertension. Their clinical status was confirmed by physical and laboratory examinations, including electrocardiography, and no history of cardiovascular diseases. All of their clinical data were within normal limits, including blood pressure, total cholesterol, and plasma glucose.

The blood pressure values of the hypertensive and normotensive subjects were the means of 2 measurements recorded $5 \mathrm{~min}$ apart in the patient in the sitting position after $15 \mathrm{~min}$ of rest. Blood samples were obtained after a fast of at least $12 \mathrm{~h}$.

Third, 150 patients who underwent coronary angiography at Showa University Hospital, Tokyo, Japan in 1997-1999 were included. AMI was diagnosed by clinical evidence of cardiac attack, ECG criteria, and serum cardiac enzyme concentrations. The AMI patients were divided into 2 subgroups: AMI with/without hypertension. The presence of conventional risk factors such as hypertension, hypercholesterolemia, diabetes mellitus and smoking was determined from the medical records prior to admission because of AMI.

All subjects gave informed consent to participate in the study, and the study was approved by the Showa University Ethics Committee. Blood samples were collected from the peripheral vein and then genomic DNA was prepared from the white blood cells.

\section{Determination of Genotypes}

AngII Type 1 Receptor 1166 Adenine/Cytosine Polymorphism The detection of the AngII type 1 receptor $1166 \mathrm{~A} / \mathrm{C}$ polymorphism was determined by polymerase chain reaction (PCR) and restriction isotyping using the restriction endonuclease Dde 1 and primers previously described by
Doria et al $!^{10}$ Alleles were visualized on $2 \%$ agarose gels stained with ethidium bromide. PCR amplified a fragment encompassing the A/C polymorphic site at the 1166 nucleotide position in the $3^{\prime}$ untranslated region of the human AngII type 1 receptor gene. The design of the primers was as follows: sense, 5'-ATAATGTAAGCTCATCCACC-3'; antisense, 5'-GAGATTGCATTTCTGTCAGT-3'. The 30$\mu 1$ reaction volume contained $100 \mathrm{ng}$ genomic DNA, 10 $\mathrm{pmol}$ of each primer, $250 \mu \mathrm{mol} / \mathrm{L} \mathrm{dNTP}, 1.0 \mathrm{mmol} / \mathrm{L} \mathrm{MgCl}$, $50 \mathrm{mmol} / \mathrm{L} \mathrm{KCl}, 10 \mathrm{mmol} / \mathrm{L}$ Tris- $\mathrm{HCl}$ at $\mathrm{pH} 8.3$, and 0.5 units of Taq polymerase. Amplification was carried out using a Thermal Cycler (Perkin Elmer 2400; CA, USA). The cycle conditions for PCR were heating for $5 \mathrm{~min}$ at $94^{\circ} \mathrm{C}, 40$ cycles of $30 \mathrm{~s}$ at $94^{\circ} \mathrm{C}, 45 \mathrm{~s}$ at $55^{\circ} \mathrm{C}$, and $45 \mathrm{~s}$ at $72^{\circ} \mathrm{C}$ as the main reaction, followed by a final extension at $72^{\circ} \mathrm{C}$ for $10 \mathrm{~min}$. After confirming that the PCR products showed exact amplification, they were digested with Dde I for $3 \mathrm{~h}$ at $37^{\circ} \mathrm{C}$. The digested products were visualized on $2 \%$ agarose gel by ethidium bromide staining.

AngII Type 2 Receptor 3123 Cytosine/Adenine Polymorphism We designed the following primers: sense, 5'GGATTCAGATTTCTCTTTGAA-3'; antisense, 5'-GCATAGGAGTATGATTTAATC-3'. PCR was performed under the same conditions used for the AngII type 1 receptor gene polymorphism, with the exception of the annealing temperature, which was set at $53^{\circ} \mathrm{C}$. After confirming DNA amplification, 10ul of the PCR product was digested with 12 units of Alu I for $3 \mathrm{~h}$ at $37^{\circ} \mathrm{C}$, then electrophoresed on $2 \%$ agarose gel with ethidium bromide staining!11,12

BK-B2 Receptor -58 Thymine/Cytosine Polymorphism The primers for PCR amplification were sense, 5'-GCAGAGCTCAGCTGGAGGAG-3', located in the promoter, and antisense 5'-CCTCCTCGGAGCCCAGAAG-3', located in the promoter/exon 1. Primers were designed from the BK-B2 receptor gene reported by Kammerer et al! ${ }^{13}$ The total reaction volume was $100 \mu \mathrm{l}$, in a mixture containing $1 \mu \mathrm{g}$ of genomic DNA, $50 \mathrm{ng}$ of each primer, $200 \mu \mathrm{mol}$ of each dNTP, $1.5 \mathrm{mmol} / \mathrm{L}$ of $\mathrm{MgCl}_{2}$, and 0.5 units of Taq DNA polymerase. The cycle conditions for PCR were an initial step of $5 \mathrm{~min}$ at $94^{\circ} \mathrm{C}$, followed by 30 cycles of $1 \mathrm{~min}$ at $94^{\circ} \mathrm{C}, 30 \mathrm{~s}$ at $58^{\circ} \mathrm{C}$, and $30 \mathrm{~s}$ at $72^{\circ} \mathrm{C}$, followed by a final extension of $5 \mathrm{~min}$ at $72^{\circ} \mathrm{C}$. PCR products were subjected to single-strand conformation polymorphism (SSCP) electrophoresis. A $10 \mu 1$ aliquot of the PCR product was diluted with $30 \mu 1$ formamide, denatured at $95^{\circ} \mathrm{C}$ for $10 \mathrm{~min}$, and subjected to SSCP analysis in a $20 \%$ polyacrylamide $(2 \times$ TBE) gel. Electrophoresis was carried out in $2 \times \mathrm{TBE}$ buffer at $24^{\circ} \mathrm{C}$ at $180 \mathrm{~V}$ for $20 \mathrm{~h}$, and the gels were then silverstained. SSCP analysis of 450 unrelated Japanese subjects was performed in the same way. Several samples representative of each genotype detected by SSCP were sequenced by fluorescent cycle sequencing to confirm the thymine (T) or cytosine $(\mathrm{C})$ at nucleotide position -58 upstream of the putative transcription start site. 
In samples obtained from 450 unrelated Japanese individuals, the 2 polymorphic alleles were disclosed by PCRSSCP electrophoresis in a $20 \%$ polyacrylamide gel.

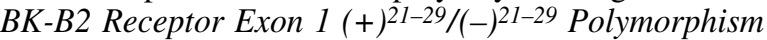
A tandem repeat polymorphism was detected in exon 1 starting at nucleotide position 12 backward from the transcription site ${ }^{13}$ Thus, exon 1 exists in 2 different lengths, 102 or 93 base pairs; that is, $(+)^{21-29}$ or $(-)^{21-29}$, respectively. Primers were designed from the BK-B2 receptor gene reported by Kammerer et al $!^{13}$ The forward and reverse primers were used for PCR amplifications: 5'-GCCCTTGAAAGATGAGCTG-3', and 5'-AACTCCCCACGACCACAG-3' for exon 1 . The total reaction volume was $50 \mu \mathrm{l}$ and included $1 \mu \mathrm{g}$ genomic DNA, $50 \mathrm{ng}$ of each primer, $1.25 \mathrm{U}$ Taq DNA polymerase, $200 \mu \mathrm{mol}$ of each dNTP, and 1.5 $\mathrm{mmol} / \mathrm{L} \mathrm{MgCl}$. The cycle conditions for PCR were an initial $5 \mathrm{~min}$ at $94^{\circ} \mathrm{C}$, followed by $1 \mathrm{~min}$ at $94^{\circ} \mathrm{C}, 1 \mathrm{~min}$ at $53^{\circ} \mathrm{C}$, and $1 \mathrm{~min}$ at $72^{\circ} \mathrm{C}$ for 40 cycles and a final extension time of $5 \mathrm{~min}$ at $72^{\circ} \mathrm{C}$. PCR products were then electrophoresed on $2 \%$ agarose gel with ethidium bromide staining.

\section{Statistical Analysis}

Differences in clinical characteristics between the subjects were examined by ANOVA for parametric data. Differences in the genotype and allelic frequencies between the groups were analyzed using the chi-squared test, and Fisher's test was used for sets with small numbers. A probability of less than $\mathrm{p}<0.05$ was taken to be significant.

\section{Results}

The clinical characteristics of the hypertensive, control and AMI subjects are shown in Table 1. Blood examination data in the hypertensive and control subjects was not significantly different, and no clinical parameters requiring treatment were seen in either subject group. The presence of complicating conventional risk factors, such as hypercholesterolemia, diabetes mellitus and smoking, between AMI subjects with/without hypertension was not significantly different.

In the samples obtained from 450 unrelated Japanese individuals, PCR-restriction fragment length polymorphism (PCR-RFLP) electrophoresis in a $2 \%$ agarose gel disclosed 2 sets of 3 genotypes for the AngII type 1 and type 2 receptor gene polymorphisms, and PCR-SSCP electrophoresis in a $20 \%$ polyacrylamide gel disclosed 1 set of 3 genotypes for the $\mathrm{BK}-\mathrm{B} 2$ receptor gene polymorphism. Fig 1 shows the AA, CC and AC genotypes of the AngII type 1 receptor 1166 polymorphism, and the $\mathrm{CC}, \mathrm{AA}$ and $\mathrm{CA}$ genotypes of the AngII type 2 receptor 3123 polymorphism. Fig 2 shows genotypes for the BK-B2 receptor gene -58 thymine/cytosine polymorphism, and DNA sequencing showed a $\mathrm{T}$ or $\mathrm{C}$ at nucleotide position -58 upstream of the putative transcrip-
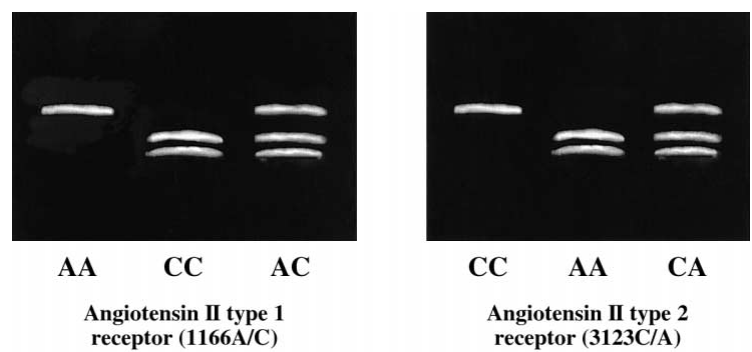

Fig 1. Agarose gel electrophoresis of polymerase chain reaction products to determine angiotensin II type 1 receptor $\mathrm{A} / \mathrm{C}$ genotype (digestion by Dde I) and angiotensin II type 2 receptor C/A genotype (digestion by Alu I).

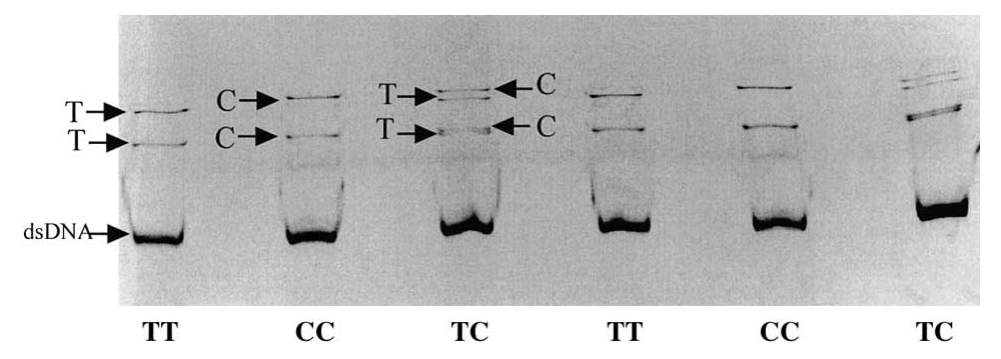

Table 2 Distributions of Genotypes and Allelic Frequencies of Angiotensin II Type 1 and Type 2 Receptors, and Bradykinin B2 Receptor Gene Polymorphisms in Hypertensive and Control Subjects

\begin{tabular}{|c|c|c|c|c|c|c|c|}
\hline \multirow{4}{*}{$\begin{array}{l}\text { Angiotensin II type } 1 \text { receptor } \\
\text { Hypertensive subjects }(n=150) \\
\text { Control subjects }(n=150)\end{array}$} & \multicolumn{3}{|c|}{ Genotype } & \multirow[t]{2}{*}{$\mathrm{X}^{2}$ test } & \multicolumn{2}{|c|}{ Allele } & \multirow[t]{2}{*}{ Odds ratio } \\
\hline & $A A$ & $A C$ & $C C$ & & $A$ & $C$ & \\
\hline & $126(84.0 \%)$ & $23(15.3 \%)$ & $1(0.7 \%)$ & $x^{2}=3.92$ & 0.92 & 0.08 & $1.65(95 \%$ CI $0.85-3.22)$ \\
\hline & $137(91.3 \%)$ & $12(8.0 \%)$ & $1(0.7 \%)$ & $p=0.14$ & 0.95 & 0.05 & $N S$ \\
\hline Angiotensin II type 2 receptor & & & & & $C$ & $A$ & \\
\hline Hypertensive subjects $(n=150)$ & & & & & 0.62 & 0.38 & $2.45(95 \%$ CI $1.70-3.54)$ \\
\hline Control subjects $(n=150)$ & & & & & 0.8 & 0.2 & $p=0.001$ \\
\hline Bradykinin B2 receptor - $58 T / C$ & $T T$ & TC & $C C$ & & $T$ & $C$ & \\
\hline Hypertensive subjects $(n=150)$ & $19(12.7 \%)$ & $88(58.6 \%)$ & $43(28.7 \%)$ & $x^{2}=9.60$ & 0.42 & 0.58 & $1.56(95 \%$ CI 1.13-2.15) \\
\hline Control subjects $(n=150)$ & $38(25.3 \%)$ & $84(56.0 \%)$ & $28(18.7 \%)$ & $p=0.008$ & 0.53 & 0.47 & $p=0.007$ \\
\hline Bradykinin B2 receptor Exon1 & $(+) /(+)$ & $(+) /(-)$ & $(-) /(-)$ & & $(+)$ & $(-)$ & \\
\hline Hypertensive subjects $(n=150)$ & $0(0 \%)$ & $0(0 \%)$ & $150(100 \%)$ & & 0 & 1 & \\
\hline Control subjects $(n=150)$ & $0(0 \%)$ & $0 \%)$ & $150(100 \%)$ & NS & 0 & 1 & NS \\
\hline
\end{tabular}

Fig 2. Single-strand conformation polymorphism (SSCP) analysis of Bradykinin B2 receptor $-58 \mathrm{~T} / \mathrm{C}$. Upper and third bands from the top are cytosine, second and fourth bands from the top are thymine. TT, thymine-thymine; TC, thymine-cytosine; CC, cytosine-cytosine. 
Table 3 Distributions of Allelic Frequencies of Angiotensin II Type 2 Receptor and Bradykinin B2 Receptor Gene Polymorphisms in Acute Myocardial Infarction Subjects With/Without Hypertension

\begin{tabular}{lccc}
\hline \hline & \multicolumn{2}{c}{ Allele } & Odds ratio \\
\hline Angiotensin II type 2 receptor & $C$ & $A$ & \\
AMI subjects with hypertension $(n=69)$ & 0.67 & 0.33 & $N S$ \\
AMI subjects without hypertension $(n=81)$ & 0.66 & 0.34 & \\
Bradykinin B2 receptor $-58 T / C$ & $T$ & $C$ & $1.66(95 \%$ CI $1.05-2.62)$ \\
AMI subjects with hypertension $(n=69)$ & 0.43 & 0.57 & $p=0.031$ \\
AMI subjects without hypertension $(n=81)$ & 0.55 & 0.45 & \\
Bradykinin B2 receptor $-58 T / C$ & $T$ & $C$ & $2.02(95 \%$ CI $1.05-3.86)$ \\
60 $<$ AMI subjects with hypertension $(n=25)$ & 0.38 & 0.62 & $p=0.033$ \\
AMI subjects without hypertension $(n=81)$ & 0.55 & 0.45 & \\
\hline
\end{tabular}

Table 4 Distributions of Allelic Frequencies of Angiotensin II Type 2 Receptor and Bradykinin B2 Receptor Gene Polymorphisms in Normotensive and Hypertensive Subjects With/Without Acute Myocardial Infarction

\begin{tabular}{|c|c|c|c|}
\hline \multirow{4}{*}{$\begin{array}{l}\text { Angiotensin II type } 2 \text { receptor } \\
\quad \text { Normotensive subjects with AMI }(n=81) \\
\quad \text { Normotensive subjects without AMI }(n=150)\end{array}$} & \multicolumn{2}{|c|}{ Allele } & \multirow[t]{2}{*}{ Odds ratio } \\
\hline & $C$ & $A$ & \\
\hline & 0.66 & 0.34 & $2.06(95 \%$ CI 1.34-3.16) \\
\hline & 0.8 & 0.2 & $p=0.001$ \\
\hline Angiotensin II type 2 receptor & $C$ & $A$ & \\
\hline Hypertensive subjects with AMI $(n=69)$ & 0.67 & 0.33 & \\
\hline Hypertensive subjects without AMI $(n=150)$ & 0.62 & 0.38 & $N S$ \\
\hline Bradykinin $B 2$ receptor $-58 T / C$ & $T$ & $C$ & \\
\hline Normotensive subjects with AMI $(n=81)$ & 0.55 & 0.45 & \\
\hline Normotensive subjects without AMI $(n=150)$ & 0.53 & 0.47 & $N S$ \\
\hline Bradykinin B2 receptor $-58 T / C$ & $T$ & $C$ & \\
\hline Hypertensive subjects with AMI $(n=69)$ & 0.43 & 0.57 & \\
\hline Hypertensive subjects without AMI $(n=150)$ & 0.42 & 0.58 & NS \\
\hline
\end{tabular}

tion start site for the BK-B2 receptor gene polymorphism.

The genotypes and allelic frequencies were in HardyWeinberg equilibrium. Table 2 shows the distributions of the genotypes and the allelic frequencies of the gene polymorphisms of AngII type 1 and type 2 receptors, and the BK-B2 receptor in hypertensive and control subjects. In the distributions of the genotype and the allelic frequency of the AngII type 1 receptor gene, there was no significant difference between the hypertensive and control subjects. However, the AngII type 2 receptor gene has been mapped to the $\mathrm{X}$-chromosome, so here we only show the allelic frequency. A significantly higher incidence of the A allele was seen in hypertensive subjects compared with controls, and the odds ratio (OR) was estimated as 2.45 (95\% confidence interval $1.70-3.54, \mathrm{p}=0.001$ ). Table 2 also shows the distributions of the genotype and allelic frequency of the BK-B2 receptor gene -58T/C polymorphism, and significantly higher incidences of the CC genotype $(\mathrm{p}=0.008)$ and $\mathrm{C}$ allele (OR 1.56 (95\% CI 1.13-2.15, $\mathrm{p}=0.007)$ ) were seen in hypertensive subjects compared with controls. However, in the distributions of the genotype and the allelic frequency

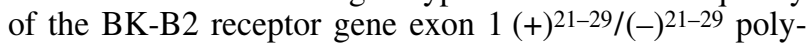
morphism, there was no polymorphism within the subjects. Furthermore, in the distributions of the genotypes and the allelic frequencies of these polymorphisms with regard to gender, there were no significant differences among the groups (data not shown). Thus, these results indicate that the AngII type 2 receptor A allele and the BK-B2 receptor $\mathrm{C}$ allele are associated with essential hypertension.

Next, we further examined these polymorphisms in AMI subjects with/without hypertension to determine whether they were associated with acceleration of atherosclerosis and the occurrence of AMI. Table 3 shows the distributions of the allelic frequencies of the gene polymorphisms of the AngII type 2 and BK-B2 receptors and it can be seen that there was no significant difference of the AngII type 2 receptor A allele between AMI subjects with/without hypertension. In contrast, a significantly higher incidence of the C allele of the BK-B2 receptor was seen in AMI subjects with hypertension compared with those without hypertension, and the OR was estimated as 1.66 (95\% CI $1.05-2.62, p=0.031$ ), which was significant, particularly in the younger AMI patients. In AMI subjects with hypertension aged less than 60 years old, a significantly higher incidence of the $\mathrm{C}$ allele of the BK-B2 receptor was detected, estimated as 2.02 (95\% CI 1.05-3.86, $\mathrm{p}=0.033)$. Therefore, BK-B2 receptor $-58 \mathrm{~T} / \mathrm{C}$ polymorphism was associated with not only with essential hypertension, but also with acceleration of atherosclerosis and the occurrence of AMI

Furthermore, the distributions of the allelic frequencies of the gene polymorphisms of the AngII type 2 receptor and BK-B2 receptor in normotensive and hypertensive subjects with/without AMI showed that the AngII type 2 receptor A allele was associated with the occurrence of AMI in normotensive subjects (Table4), so this polymorphism might be related to other coronary risk factors. The BK-B2 receptor C allele was not associated with the occurrence of AMI in either normotensive or hypertensive subjects, so it is either not associated directly with the occurrence of AMI or hypertension may strongly influence the $\mathrm{C}$ allele. 


\section{Discussion}

From the genetic basis of essential hypertension and coronary heart disease, the ECTIM study showed that the ACE DD genotype was more frequent in patients with MI than in control subjects 14,15 Tiret et al also showed that the association between the ACE DD genotype and MI was increased in a subset of patients who also carried the AngII type $1 \mathrm{C}$ allele 15 and other studies have confirmed the association of the ACE D allele and the AngII type 1 receptor $\mathrm{A} / \mathrm{C}$ genotype with an increased risk of essential hypertension and MI! ${ }^{16-19}$

The cellular effects of AngII are mediated by 2 structurally distinct receptor subtypes, the AngII type 1 and type 2 receptors, and most of known biological functions are mediated by the type 1 receptor, which is widely distributed in adult tissues?20,21 The expression of the AngII type 2 receptor is abundant in fetal tissues and scanty in adult tissues ${ }^{2-25}$ and the mechanism of the type 2 receptor is still obscure. This receptor is re-expressed in MI, cardiac hypertrophy and vascular injury, 26,27 which suggests that it is activated in various pathophysiological states and works cardioprotectively against the type 1 receptor ${ }^{28,29}$

In addition, AngII receptor antagonists are now used clinically for hypertension and congestive heart failure. Their pharmacological mechanism is inhibition of the AngII type 1 receptor and stimulation of the type 2 receptor, 28,30 but few studies have investigated the association between AngII type 2 receptor polymorphism and diseases.

Our results suggest that AngII type 1 receptor polymorphism is not associated with essential hypertension, but the AngII type 2 receptor A allele was associated with its occurrence. This polymorphism was not associated with AMI with/without hypertension, therefore it is unclear whether the AngII type 2 receptor A allele was associated with the acceleration of atherosclerosis by hypertension and the occurrence of AMI. However, this polymorphism was associated with the occurrence of AMI in normotensive subjects, so it might be related to other coronary risk factors.

It was reported that the AngII type 1 receptor $1166 \mathrm{~A} / \mathrm{C}$ polymorphism might be a marker in linkage disequilibrium with an unidentified functional variant that could affect the regulation of the gene in response to AngII31,32 In addition to the AngII type 1 receptor polymorphism, it was suggested that the AngII type 2 receptor polymorphism in itself does not cause cardiovascular disorders directly, but that this polymorphism may contribute to the development and progression of cardiovascular disease, started by other factors, such as the activity of plasma renin and its uptake by certain tissues that leads to local activation of the RAS. Therefore, this genetic variation becomes very important when combined with other factors.

Bradykinin in the kallikrein-kinin system is a vasoactive nonpeptide of the kinin family released from kininogenes via the proteolytic activity of kallikreins ${ }^{33,34}$ It plays an important role in the cardiovascular system, affecting blood pressure regulation, cell proliferation and matrix synthesis by fibroblasts $, 35,36$ and also acts cardioprotectively on the myocardium 34,37 Bradykinin acts mainly as a local hormone by activating specific receptors, known as the B1 and B2 receptors, the latter mediating most of the inflammatory and cardiovascular effects 38,39 The human B2 receptor gene is implicated as a candidate in the complex genetic underpinnings of essential hypertension and cardiovascular diseases. 40 Subsequent studies of the genomic structure have shown that it is characterized by 3 polymorphisms located in each of the 3 exons and 1 polymorphism located in the promoter region9,13,41 Braun et al reported that the polymorphism of the promoter region may influence the transcription rate of the gene. They initiated in vitro transfection experiments in human embryonic kidney cells, and performed luciferase reporter gene assays to examine the effect of the 2 different alleles of the promoter on the transcription rate. There were differences in the extent of luciferase expression: the luciferase promoter assay of -58T was found to be higher than that of $-58 \mathrm{C}$ ? Kammerer et al also reported that the promoter and exon 1 regions are related to transcription rate ${ }^{13}$ We previously reported that the low transcriptional activity of the BK-B2 receptor promoter polymorphism may cause the development of essential hypertension, and in our present study, the BK$\mathrm{B} 2$ receptor $\mathrm{C}$ allele was associated with not only with the occurrence of essential hypertension, but also with the acceleration of atherosclerosis by hypertension and the occurrence of AMI. However, this polymorphism was not associated directly with the occurrence of AMI. The low transcriptional activity of the BK-B2 receptor promoter may influence the transcription rate of the gene, and the occurrence of diseases, but in the Japanese population the BK-B2 receptor exon $1(+)^{21-29} /(-)^{21-29}$ polymorphism does not have an effect on the occurrence of essential hypertension and AMI.

We analyzed the polymorphisms of the AngII type 1 and type 2 receptors and the BK-B2 receptor, and found significant differences of genotypes and allelic frequencies in the AngII type 2 receptor C/A and the BK-B2 receptor -58T/C polymorphisms between subjects with essential hypertension and control subjects. These polymorphisms are probably associated with an increased responsiveness to AngII and we conjecture that they promote the occurrence of essential hypertension. Further, the BK-B2 receptor -58T/C polymorphism was also associated with the acceleration of atherosclerosis and the occurrence of AMI. These genetic variations contribute to individual heterogeneity in the status of the RAS and kallikreins-kinin system, and thereby modify the role of these systems in essential hypertension and AMI.

In conclusion, genetic variations in the renin-angiotensin and kallikrein-kinin systems could prove to be significant pathophysiological mechanisms affecting essential hypertension and AMI, and genetic differences appear to be a new coronary risk factor for these diseases. This new marker provides a valuable tool to assess a patient's risk and the occurrence of these diseases may be able to be reduced by genetic management.

\section{References}

1. Waordf R: Familial aggregation and genetic epidemiology of blood pressure. In: Largh JH, Brenner BM, editors. Hypertension: Pathophysiology, diagnosis and management. New York: Raven Press, 1990: $81-100$

2. O'Donnell CJ, Lindpaintner K, Larson MG, Rao VS, Ordovas JM, Schaefer EJ, et al: Evidence for association and genetic linkage of the angiotensin-converting enzyme locus with hypertension and blood pressure in men but not women in the Framingham study. Circulation 1998; 97: 1766-1772

3. Fornage M, Amos CI, Kardia S, Sing CF, Turner ST, Boerwinkle E: Variation in the region of the angiotensin-converting enzyme gene influences interindividual differences in young white males. Circulation 1998; 97: 1773-1779

4. Jeunemaitre X, Soubrier F, Kotelevtsev YV, Lifton RP, Williams 
CS, Charru A, et al: Molecular basis of human hypertension: Role of angiotensinogen. Cell 1992; 71: 169-180

5. Bonnardeaux A, Davies E, Jeunemaitre X, Fery I, Tiret L, Cambien $\mathrm{F}$, et al: Angiotensin II type 1 receptor gene polymorphisms in human essential hypertension. Hypertension 1994; 24: 63-69

6. Cambien F, Poirier O, Lederf L, Evans A, Cambous JP, Arveiler D, et al: Deletion polymorphism in the gene for angiotensin-converting enzyme is a potent risk factor for myocardial infarction. Nature 1992; 359: 641-644

7. Tiret L, Bonnardeaux A, Poirier O, Ricard S, Marques-Vidal P, Evans A, et al: Synergistec effects of angiotensin-converting enzyme and angiotensin-II type 1 receptor gene polymorphisms on risk of myocardial infarction. Lancet 1994; 344: 910-913

8. Mukae S, Aoki S, Itoh S, Nishio K, Iwata T, Ueda H, et al: Promoter polymorphism of the $\mathrm{B} 2$ bradykinin receptor gene is associated with essential hypertension. Jpn Circ J 1999; 63: 759-762

9. Braun A, Kammerer S, Maier E, Bohme E, Roscher AA: Polymorphism in the gene for the human B2-bradykinin receptor: New tools assessing a genetic risk for bradykinin-associated diseases. Iттипоpharmacology 1996; 33: 32-35

10. Doria A, Warram JH, Krolewski AS: Dde I polymorphism in the AT1R gene. Hum Mol Genet 1994; 3: 1444

11. Takami S, Katsuya T, Rakugi H, Sato N, Higaki J, Ogihara T, et al: Angiotensin II type 1 receptor gene polymorphism is associated with increase of left ventricular mass but not with hypertension. Am J Hypertens 1998; 11: 316-321

12. Katsuya T, Horiuchi M, Minami S: Genomic organization and polymorphism of human angiotensin II type 2 receptor: No evidence for its gene mutation in two families of human premature ovarian failure syndrome. Mol Cell Endocrinol 1997; 127: 221-228

13. Kammerer S, Braun A, Arnold N, Roscher AA: The human bradykinin $\mathrm{B} 2$ receptor gene: Full length cDNA, genomic organization and identification of the regulatory region. Biochem Biophys Res Commun 1995; 211: 226-233

14. Cambien F, Poirier O, Lederf L, Evans A, Cambous JP, Arveiler D, et al: Deletion polymorphism in the gene for angiotensin-converting enzyme is a potent risk factor for myocardial infarction. Nature 1992; 359: $641-644$

15. Tiret L, Kee F, Poirier O, Nicaud V, Lecerf L, Evans A, et al: Deletion polymorphism in angiotensin-converting enzyme gene associated with parental history of myocardial infarction. Lancet 1993; 341: 991-992

16. Wang WYS, Zee RYL, Morris BJ: Association of angiotensin II type 1 receptor gene polymorphism with essential hypertension. Clin Genet 1997; 51: 31-34

17. Bonnardeaux A, Davies E, Jeunemaitre X, Fery I, Tiret L, Cambien F, et al: Angiotensin II type 1 receptor gene polymorphisms in human essential hypertension. Hypertension 1994; 24: $63-69$

18. Mattu RK, Needham EW, Galton DJ, Frangos E, Clark AJ, Caulfield M: A DNA variant at the angiotensin-converting enzyme gene locus associates with coronary artery disease in the Caerphilly Heart Study. Circulation 1995; 91: 270-274

19. Gardemann A, Weiss T, Schwartz O, Eberbach A, Katz N, Hehrlein FW, et al: Gene polymorphism but not catalytic activity of angiotensin I-converting enzyme is associated with coronary artery disease and myocardial infarction in low-risk patients. Circulation 1995; 92: $2796-2799$

20. Timmermans PB, Wong PC, Chiu AT, Herblin WF, Benfield P, Carini DJ, et al: Angiotensin II receptors and angiotensin II receptor antagonists. Pharmacol Rev 1993; 45: 205-251

21. Chiu AT, Herblin WF, McCall DE, Ardecky RJ, Carini DJ, Duncia $\mathrm{JV}$, et al: Identification of angiotensin II receptor subtypes. Biochem
Biophys Res Commun 1989; 165: 196-203

22. Koike G, Horiuchi M, Yamada T, Szpirer C, Jacob HJ, Dzau VJ: Human type 2 angiotensin II receptor gene: Cloned, mapped to the $\mathrm{X}$ chromosome, and its mRNA is expressed in the human lung. Biochem Biophys Res Commun 1994; 203: $1842-1850$

23. Koike G, Winer ES, Horiuchi M, Brown DM, Szpirer C, Dzau VJ, et al: Cloning, characterization, and mapping of the rat type 2 angiotensin II receptor gene. Hypertension 1995; 26: $908-1002$

24. Grady EF, Sechi LA, Griffin CA, Schambelan M, Kalinyak JE: Expression of AT2 receptor in the developing rat fetus. J Clin Invest 1991; 88: 921 -933

25. Millan MA, Jacobowitz DM, Aguilera G, Catt KJ: Differential distribution of AT1 and AT2 angiotensin II receptor subtypes in the rat brain during development. Proc Natl Acad Sci USA 1991; 88: 1144011444

26. Nio Y, Matsubara H, Murasawa S, Kanasaki M, Inada M: Regulation of gene transcription of angiotensin II receptor subtypes in myocardial infarction. J Clin Invest 1995; 95: 46-54

27. Lopez J, Lorell BH, Ingelfinger JR, Weinberg EO, Schunkert H, Diamant D, et al: Distribution and function of cardiac angiotensin AT1- and AT2-receptor subtypes in hypertrophied rat heart. Am J Physiol 1994; 36: H844-H852

28. Jalowy A, Schulz R, Dorge H, Behrends M, Heusch G: Infarct size reduction by AT1-receptor blockade through a signal cascade of AT2-receptor activation, bradykinin and prostaglandins in pigs. $J \mathrm{Am}$ Coll Cardiol 1998; 32: 1787-1796

29. Kuizinga MC, Smits JFM, Arends JW, Daemen MJAP: AT2-receptor blockade reduces cardiac interstitial cell DNA synthesis and cardiac function after rat myocardial infarction. J Mol Cell Cardiol 1998; 30: $425-434$

30. Tsutsumi Y, Matsubara H, Ohkubo N, Mori Y, Nozawa Y, Murasawa $\mathrm{S}$, et al: Angiotensin II type 2 receptor is upregulated in human heart with interstitial fibrosis, and cardiac fibroblasts are the major cell type for its expression. Circ Res 1998; 83: 1035-1046

31. Bonnardeaux A, Davies E, Jeunemaitre X, Fery I, Charru A, Clauser $\mathrm{E}$, et al: Angiotensin II type 1 receptor gene polymorphisms in human essential hypertension. Hypertension 1994; 24: 63-69

32. van Geel PP, Pinto YM, Buikema H, van Gilst WH: Is the A1166C polymorphism of the angiotensin II type 1 receptor involved in cardiovascular disease? Eur Heart J 1998; 19: G13-G17

33. Hall JM: Bradykinin receptors. Gen Pharmacol 1997; 28: 1-6

34. Bhoola KD, Figueroa CD, Worthy K: Bioregulation of kinins, kallikreins, kininogens, and kininases. Pharmacol Rev 1992; 44: 180

35. Regoli D, Barabe J: Pharmacology of bradykinin and related kinins. Pharmacol Rev 1980; 32: 1-46

36. Burch RM, Kyle DJ: Recent developments in the understanding of bradykinin receptors. Life Sci 1992; 50: 829-838

37. Hess JF, Borkowski JA, Young GS, Strader CD, Ransom RW: Cloning and pharmacological characterization of a human bradykinin (BK-2) receptor. Biochem Biophys Res Commun 1992; 184: 260-268

38. Farmer SG, Burch RM: Biochemical and molecular pharmacology of kinin receptors. Annu Rev Pharmacol Toxicol 1992; 32: 511-536

39. Seguin L, Widdowson PS, Giesen-Crouse E: Existence of three subtypes of bradykinin B2 receptors in guinea pig. J Neurochem 1992; 59: $2125-2133$

40. Wang DZ, Chao L, Chao J: Hypotension in transgenic mice overexpressing human bradykinin B2 receptor. Hypertension 1997; 29: 488493

41. Braun A, Kammerer S, Bohme E, Muller B, Roscher AA: Identification of polymorphic sites of the human bradykinin $\mathrm{B} 2$ receptor gene. Biochem Biophys Res Commun 1995; 211: 234-240 